\title{
Antioxidant and Antiobesity Activity of Solvent Fractions from Red Garlic
}

Cho Rong Hwang', Jung Hae Shin', Min Jung Kang ${ }^{1}$, Soo Jung Lee ${ }^{2}$ and Nak Ju Sung²

${ }^{1}$ Namhae Garlic Research Institute, Namhae 668-812, Korea

${ }^{2}$ Department of Food Science and Nutrition, Institute of Agriculture and Life Science, Gyeangsang National University, Jinju 660-701, Korea

Received April 13, 2012 /Revised June 29, 2012 /Accepted July 6, 2012

\begin{abstract}
Development of garlic processing products by thermal treatment and researched biological activity of a new product, red garlic. Red garlic $\mathrm{MeOH}$ extract was graduated by solvents, such as hexane, chloroform, ethyl acetate, butanol, and water, in order. Each solvent fraction was dried by a rotary evaporator and then resolved in water for analysis of its antioxidant and antiobesity activity. Browning compounds of red garlic fractions were the highest in the chloroform fraction. Total phenolic compounds and flavonoid content were highest in the hexane fraction. The chloroform fraction showed significantly higher activity in DPPH, ABTS radical scavenging activity, and antioxidant activity by FRAP. We propose that the antioxidant activity of the solvent fractions from red garlic was revealed interaction of browning compounds, total phenolic compounds, and flavonoids. Due to the higher activity of the shown fraction, the hexane and the chloroform fractions were have high contents of these compounds. Below $500 \mathrm{\mu g} / \mathrm{ml}$, pancreatic lipase inhibition activity was significantly increased by sample concentration. And chloroform fraction, have the highest inhibition activity was shown over the $40 \%$. In 3T3-L1 cells, the lipid accumulation inhibition activity was lower in the hexane and in the chloroform fraction than in the other fractions.
\end{abstract}

Key words : Red garlic, solvent fraction, antioxidant activity, anti-obesity activity

\section{서 론}

식품의 색은 관능적 특성 및 식품선택의 중요한 기준이 되 는데, 효소나 열처리 과정을 통한 색의 변화는 식품 가공 측면 에서 볼 때 원하는 색을 변색시킨다는 부정적인 측면도 있으 나 원래 식품에서 없던 색이 발색되어 관능적 특성을 개선시 키는 긍정적인 면을 활용하기도 한다. 열처리를 통한 식품의 가공은 갈변반응을 유도함으로서 Maillard 반응에 의해 색의 변화를 가져오고, 페놀성 화합물의 추출을 촉진하거나 항산화 활성이 증가하여 생리활성이 증가되는 특성을 부여함으로써 [18] 식품의 이화학적 특성뿐만 아니라 생리활성의 변화를 유 발하여 기능성을 강화하게 된다. 갈변반응과 관련하여 부정적 인 측면과 긍정적인 예로써 생마늘은 박피, 절단, 다짐 등의 가공 중에 polyphenol oxidase (PPO)가 polyphenol류와 효소 적 산화반응을 일으키기 때문에 갈변이 일어나 품질의 저하를 가져오게 된다[6]. 하지만, 열처리 가공을 거침으로써 제조되 는 흑마늘은 생마늘의 단점이 되는 매운 맛과 향이 감소하고, 젤리와 유사한 조직감을 가지며, 전체적으로 검은색을 유지하 는 새로운 가공품이 되고 항산화 활성, 항고지혈증 효과 등이 생마늘에 비해 증가된다[24]. 인삼의 경우에도 증삼 및 건조하 는 과정을 거치면서 저장성이 증가되고, 갈색화된 홍삼을 제 조할 수 있는데, 이 과정에서 비효소적 갈변에 의해 생성되는

*Corresponding author Tel : +82-772-1431, Fax : +82-772-1439

E-mail : snakju@gsnu.ac.kr
갈변물질의 정도는 항산화능과 비례하는 특성을 가진다고 보 고되어 있다[16].

갈변반응 생성물질은 대표적인 생리활성으로 항산화 활성 을 가지는데, 이는 갈변반응의 중간생성물인 reductone의 수 소공여능에 의존하거나[17], melanoidine이 중금속이온의 작 용을 봉쇄하거나 또는 분해산물들이 산소를 포획하는 라디칼 을 형성하기 때문으로 추정되고 있다[30]. 항산화 활성 이외에 도 Maillard 반응 생성물은 식품내 대표적인 발암물질인 N-nitrosamine의 생성 전구물질인 아질산염의 소거활성이 높아 위 내 발암물질의 생성억제에 기여하며[11], heterocyclic amine 에 대한 항돌연변이 활성[12] 등의 생리활성을 가지는 것으로 보고되어 있다. 현재까지 진행된 Maillard 갈변물질에 대한 대부분의 연구는 항산화 활성 규명, 모델 반응계를 이용한 반 응기작의 규명에 관한 것이 주를 이루고 있고, 식품내 Maillard 반응물질과 관련하여서는 홍삼 중의 갈변물질 규명 및 생리활성에 대한 연구 $[16,17,28]$ 가 다수 진행된 바 있다.

최근에는 대표적인 조미향신 채소인 마늘의 가공품으로 흑 마늘이 개발되어 항산화 활성[5,23,31], 운동에 의한 체내 지질 산화 억제작용[13], 항고지혈증 작용[8], 항비만 활성[20] 등과 관련한 연구들이 진행되어 있다. 흑마늘의 가공도 열처리에 의한 Maillard 갈변의 원리에 기초하고 있는데 인삼의 예에서 볼 수 있듯이 갈변반응의 조절만으로도 수삼, 백삼, 홍삼 및 흑삼 등으로 색, 형태, 물성, 저장성 등의 특성이 차이가 나도 록 가공이 가능하며 그 가공정도에 따라 차별화되는 생리활성 및 특성을 가지게 된다. 이러한 가공법의 차별화나 변형은 다 
양한 생리활성과 특성을 가지는 맞춤형 기능식품을 선호하는 현대인들의 소비성향과도 부합하고 있다. 이러한 관점에서 본 연구진은 마늘의 가공조건을 변화하여 기존의 생마늘 및 흑마 늘과 차별화되는 색상과 물리적 특성을 가지는 홍마늘을 개발 하여 제조과정 중의 특성[9], 생마늘, 흑마늘과의 생리활성 비 교 연구 $[19,25]$, 항염증활성[7] 등에 대해 다양한 연구를 추진 하고 있다. 본 연구에서는 홍마늘 생리활성 규명을 위한 연구 의 일환으로 홍마늘 용매 분획물을 제조하여 항산화 활성 및 항비만 활성을 규명하기 위한 기초자료를 확보하고자 하였다.

\section{재료 및 방법}

\section{시료의 제조}

홍마늘은 경남 남해산 깐마늘을 이용하여 본 연구진이 특허 출원한(제 10-2011-0109281호) 방법에 따라 $-80^{\circ} \mathrm{C}$ 에서 24시간 동결건조 시킨 후 뚜껑이 있고 밀폐가 되는 용기에 넣어 $80^{\circ} \mathrm{C}$ 의 항온항습기에서 36 시간 숙성시켰다. 이어 온도 $60^{\circ} \mathrm{C}$, 습도 $60 \%$ 의 조건에서 12 시간 숙성시킨 다음 $60^{\circ} \mathrm{C}$ 에서 5 시간 동안 건조시켜 완성하였다.

\section{용매 분획물의 제조 및 추출수율 측정}

분쇄한 홍마늘 시료에 약 10 배의 메탄올을 가하여 $60^{\circ} \mathrm{C}$ 의 수욕상에서 환류냉각하면서 2회 반복 추출하여 메탄올 조추 출물을 얻었다. 이것을 회전식 진공증발기로 추출용매를 제거 한 다음 메탄올과 물 혼합액 $(1: 9, \mathrm{v} / \mathrm{v})$ 에 재용해하고, 순차적으 로 hexane, chloroform, ethyl acetate, butanol을 각각 가하여 2 회씩 반복 추출해 각각의 용매 분획물을 얻었으며, 잔사를 물분획물로 하였다. 5 종의 용매분획물은 회전식 진공증발기 로 완전건고 시킨 다음 일정량을 취하여 항산화 활성 측정용 시료로 사용하였다.

홍마늘 용매 분획물의 추출수율은 건조 및 추출 전 - 후의 시료 중량을 측정하여 계산하였다.

\section{용매 분획물의 갈색도 측정}

갈색도는 각 용매 분획물의 농도를 $100 \mu \mathrm{g} / \mathrm{ml}$ 로 조정하여 분광광도계(Optizen 2120UV, Mecasys Co. Ltd., Korea)로 420 $\mathrm{nm}$ 에서 증류수를 대조로 하여 측정한 흡광도 값으로 나타내 었다.

\section{총 페놀 및 플라보노이드 정량}

총 페놀 함량은 $1,000 \mu \mathrm{g} / \mathrm{ml}$ 농도의 홍마늘 용매 분획물 1 ml에 Foline-Ciocalteau 시약 및 $10 \% \mathrm{Na}_{2} \mathrm{CO}_{3}$ 용액을 각각 $1 \mathrm{ml}$ 씩 차례로 가하여 실온에서 1 시간 반응시킨 후 $700 \mathrm{~nm}$ 에 서 흡광도를 측정하였다. 총 플라보노이드는 분획물 $1 \mathrm{ml}$ 에 $10 \%$ aluminum nitrate $0.1 \mathrm{ml}, 1 \mathrm{M}$ potassium acetate $0.1 \mathrm{ml}$ 및 ethanol $4.3 \mathrm{ml}$ 를 차례로 혼합하고 실온에서 40 분간 반응시
킨 다음 $415 \mathrm{~nm}$ 에서 흡광도를 측정하였다. 홍마늘 용매 분획 물의 총 페놀 및 플라보노이드 함량은 표준물질로 각각 caffeic acid 및 quercetin (Sigma Co., St. Louis, MO, USA)을 이용한 검량선에 의해 계산하였다.

\section{$\mathrm{DPPH}$ 라디칼 소거능 측정}

DPPH (1,1-diphenyl-2-picryl-hydrazyl) 라디칼 소거능은 일정 농도별로 조정된 홍마늘 용매 분획물 $1 \mathrm{ml}$ 에 메탄올에 용해하여 $5 \mathrm{mg} / 100 \mathrm{ml}$ 의 농도로 제조한 DPPH 용액 $1 \mathrm{ml}$ 을 가하여 혼합한 다음 실온에서 10 분간 반응시킨 후 $525 \mathrm{~nm}$ 에서 흡광도를 측정하였다. 소거능은 시료첨가구와 무첨가구의 흡 광도 비 $(\%)$ 로 나타내었다.

\section{ABTS 라디칼 소거능 측정}

ABTS (2,2'-azinobis-3-ethylbenzothiazoline-6-sulphonic acid) 라디칼 소거능은 $7 \mathrm{mM}$ ABTS 용액에 potassium persulfate를 $2.4 \mathrm{mM}$ 이 되도록 용해시킨 다음 암실에서 12 16시간 동안 반응시킨 후 이를 $414 \mathrm{~nm}$ 에서 흡광도가 1.5 가 되도록 증류수로 조정하여 사용하였다. 농도 조정된 $\mathrm{ABTS}$ 용액 $3 \mathrm{ml}$ 에 농도별 분획물 각 $1 \mathrm{ml}$ 를 가하여 실온에서 10 분간 반응시킨 후 $414 \mathrm{~nm}$ 에서 흡광도를 측정하여 시료첨가구와 무첨가구의 흡광도 비 $(\%)$ 로 나타내었다.

\section{FRAP법에 의한 항산화능}

홍마늘 용매 분획물에 대한 FRAP (ferric reducing antioxidant power) 측정은 pH 3.6의 $300 \mathrm{mM}$ acetate buffer, 40 $\mathrm{mM} \mathrm{HCl}$ 에 용해한 $10 \mathrm{mM} \mathrm{TPTZ} \mathrm{(2,4,6-tripyridyl-s-triazine)}$ 용액 및 $20 \mathrm{mM} \mathrm{FeCl}_{3} \cdot 6 \mathrm{H}_{2} \mathrm{O}$ 를 각각 $10: 1: 1(\mathrm{v} / \mathrm{v} / \mathrm{v})$ 의 비율로 미리 혼합한 다음 $37^{\circ} \mathrm{C}$ 의 수욕상에서 가온한 뒤 FRAP 측정 용 기질로 사용하였다. 96 well plate에 시료액 $40 \mu \mathrm{ll}$ FRAP 기질액 $100 \mu \mathrm{l}$ 및 증류수 $40 \mu 1$ 를 차례로 혼합하여 $37^{\circ} \mathrm{C}$ 에서 4 분간 반응시킨 후 $593 \mathrm{~nm}$ 에서 흡광도를 측정하였으며, $\mathrm{FeSO}_{4} \cdot 7 \mathrm{H}_{2} \mathrm{O}$ 를 표준물질로 하여 얻은 표준검량선으로부터 계산하였다.

\section{Lipase 활성 저해능}

Lipase 저해효과 측정은 Saisuburamaniyan 등[22]의 방법 을 변형하여 사용하였다. 각 천연식물류 추출물 $0.25 \mathrm{ml}, 800$ unit/ml lipase $0.5 \mathrm{ml}, 0.05 \mathrm{M}$ potassium phosphate buffer ( $\mathrm{pH} 6.5) 0.5 \mathrm{ml}$ 을 차례로 가한 후 혼합하였다. $37^{\circ} \mathrm{C}$ 에서 15 분 간 전 처리한 다음 $10 \%$ isooctane에 용해시킨 olive oil 1.25 $\mathrm{ml}$ 을 첨가하여 $37^{\circ} \mathrm{C}$ 에서 20 분간 진탕배양 하였다. Acetone $5 \mathrm{ml}$ 로 반응을 정지시킨 후 $5 \%$ cupric acetate $1 \mathrm{ml}$ 를 첨가하 여 혼합한 뒤 상온에서 정치하여 상층액 $1 \mathrm{ml}$ 를 $720 \mathrm{~nm}$ 에서 흡광도를 측정하였다. Lipase 저해효과 $(\%)$ 는 $\{1-$ (시료를 첨 가하지 않은 대조군의 흡광도-시료를 첨가한 반응군의 흡광 
도)/시료를 첨가하지 않은 대조군의 흡광도 $\times 100$ 식으로부터 산출하였다.

\section{T3-L1 세포를 이용한 항비만 활성 측정}

실험에 사용한 3T3-L1 전구지방세포는 한국세포주은행 (KCLB)으로부터 분양 받았으며, $10 \%$ bovine serum (GIBCO, Rockville, $\mathrm{MD}, \mathrm{USA}$ )과 $1 \% \mathrm{P} / \mathrm{S}$ (Penicillin/streptomycin)이 포함된 DMEM (Dulbecco's Modification of Eagle's Medium, $\mathrm{GIBCO}$, Rockville, $\mathrm{MD}, \mathrm{USA}$ ) 배지를 가하여 $5 \% \mathrm{CO}_{2}, 37^{\circ} \mathrm{C}$ 조건의 incubator (3517-02, Shellab Co., Cornelius, USA)에서 배양하였다.

\section{세포독성 평가}

3T3-L1 전지방세포를 $5 \times 10^{4} \mathrm{cell} / \mathrm{ml}$ 이 되도록 현탁하여 96 well plate에 $90 \mu \mathrm{l}$ 씩 분주하고 $5 \% \mathrm{CO}_{2}, 37^{\circ} \mathrm{C}$ 조건의 incubator 에서 24 시간 동안 배양한 다음, 배지를 모두 제거하고 혈청이 포함되지 않은 배지를 $90 \mu 1$ 씩 첨가하였다. 여기에 최종 농도 가 25,50 및 $100 \mu \mathrm{g} / \mathrm{ml}$ 이 되도록 배양액에 희석한 시료를 $10 \mu \mathrm{l}$ 씩 가한 뒤 24시간 동안 배양하였다. 그 후, CCK-8 (Colorimetric Cell Counting kit-8, Dojindo Laboratories, Kumamoto, Japan) 용액을 $10 \mu l$ 씩 분주하여 3시간 동안 배양 한 후 ELISA reader (Victor ${ }^{\mathrm{TM}}$ X3, Perkin Elmer, USA)를 이용 하여 $450 \mathrm{~nm}$ 의 파장에서 흡광도를 측정하였다. 세포 생존율은 시료를 처리하지 않은 대조군의 흡광도 값에 대한 시료 처리 군의 흡광도 값의 비로 나타내었으며, 각 실험은 독립적으로 3 회 반복 실행하여 평균치를 구하였다.

\section{세포분화 유도 및 Oil red $\mathrm{O}$ 염색을 통한 지방축적량 측정}

3T3-L1 전지방세포를 $1 \times 10^{4} \mathrm{cell} / \mathrm{ml}$ 의 suspension 용액으 로 만들어 6-well plate에 분주한 후 $10 \% \mathrm{BS}$ 및 $1 \% \mathrm{P} / \mathrm{S}$ 가 포 함된 DMEM 배지를 2일 주기로 교체하면서 배양하였다. 세 포가 confluent된 후 48시간 더 배양 한 다음 DMEM, $10 \%$ FBS (fetal bovine serum), 1\% P/S, $10 \mu \mathrm{g} / \mathrm{ml}$ insulin, $1 \mu \mathrm{M}$ dexamethasone 및 $0.5 \mathrm{mM}$ isobuthylmethylxanthine이 첨가 된 배지로 교체하여 분화를 유도하였다. 여기에 시료 추출물 을 $100 \mu \mathrm{g} / \mathrm{ml}$ 의 농도로 처리한 다음, $5 \% \mathrm{CO}_{2}, 37^{\circ} \mathrm{C}$ 조건의 incubator에서 2일간 배양한 후, 분화유지 배지(DMEM, $10 \%$ $\mathrm{FBS}, 1 \% \mathrm{P} / \mathrm{S}, 10 \mathrm{\mu g} / \mathrm{ml}$ insulin)로 교체하고 시료 추출물을 $100 \mathrm{\mu g} / \mathrm{ml}$ 의 농도로 재처리하였다. 다시 48시간 후 DMEM, $10 \% \mathrm{FBS}, 1 \% \mathrm{P} / \mathrm{S}$ 및 시료추출물을 함유한 배지로 교환한 후 2 일 간격으로 8 일 동안 배양하였다. 최종 배양 후 배지를 제거 하고, 세포를 고정시키기 위해 $10 \%$ formaldehyde를 $500 \mu \mathrm{l}$ 씩 각 well에 넣고 $4^{\circ} \mathrm{C}$ 에서 1 시간 동안 유지시켰다. Formaldehyde를 제거하고 PBS로 세 번 씻어낸 후 Oil red O (Sigma Co., St. Louis, MO, USA)를 isopropyl alcohol에 $0.5 \%$ 농도로 용해한 후 증류수와 3:2(v:v)의 비율로 혼합하여
제조한 염색시약을 $500 \mu \mathrm{l}$ 씩 가하여 상온에서 1 시간 동안 염 색하였다. 염색된 세포는 PBS로 3번 세척한 후 현미경(IX71, Olympus, Tokyo, Japan)으로 관찰하였으며, 지방에 염색된 염색시약을 isopropyl alcohol로 추출하여 ELISA reader (Victor ${ }^{\mathrm{TM}}$ X3, Perkin Elmer, USA)로 $595 \mathrm{~nm}$ 에서 흡광도 값 을 측정하였다. 지방 축적율은 시료를 처리하지 않은 대조군 의 흡광도 값에 대한 시료 처리군의 흡광도 값의 비로 나타내 었다.

\section{통계처리}

반복 실험하여 얻은 결과는 SPSS 12.0 package를 사용하여 분산분석 하였으며, 결과는 평균표준편차로 나타내었다. 각 실험군에 대한 유의성 검정은 분산분석을 한 후 $p \times 0.05$ 수준에 서 Duncan's multiple test를 실시하였다.

\section{결과 및 고찰}

\section{추출 수율 및 갈변 물질 함량}

홍마늘 용매 분획물의 추출 수율(data not shown)은 buta$\mathrm{nol}$ 분획물이 $8.21 \%$ 로 가장 높았으며, hexane, chloroform, ethyl acetate 및 물 분획물은 각각 $0.29,0.38,0.10$ 및 $0.83 \%$ 로 모두 $1 \%$ 이하였다.

분획물의 갈변물질 함량을 $420 \mathrm{~nm}$ 에서 흡광도 값으로 나타 낸 결과는 Fig. 1 과 같다. Chloroform 분획물의 흡광도 값은 0.80 으로 타 분획물에 비해 유의적으로 높아, hexane 분획물 (0.46)과 물 분획물 $(0.45)$ 에 비해 약 1.7 배 정도 높은 함량이었 다. Ethyl acetate 및 butanol 분획물의 갈변도는 0.30 이하였다.

Maillard 반응에서는 반응 온도가 낮을수록 갈변도가 계속

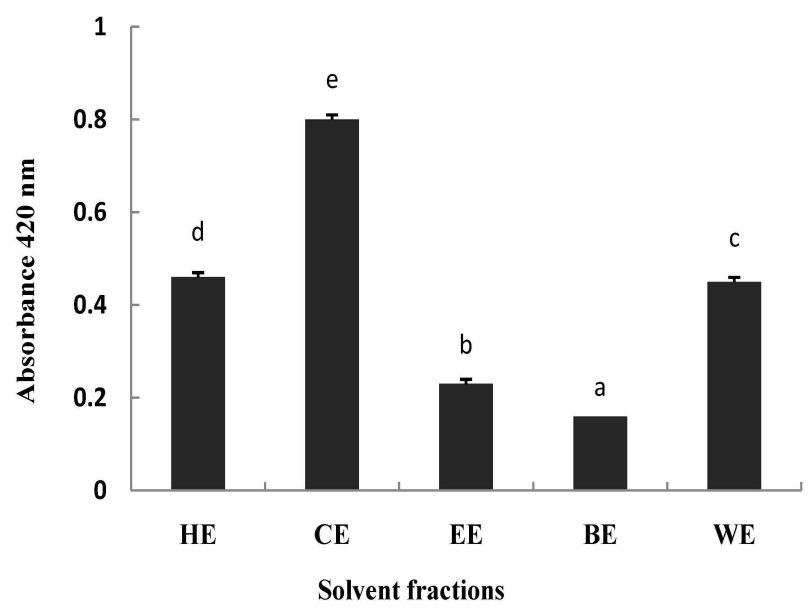

Fig. 1. Browning intensity of different solvent fractions from red garlic. HE: hexane extract, $\mathrm{BE}$ : butanol extract, $\mathrm{CE}$ : chloroform extract, EE: ethyl acetate extract, WE: water extract. Each value represents mean \pm SD $(n=3) .{ }^{a-e}$ Means with different superscripts in the bars are significantly different at $p<0.05$. 
증가하지만 고온에서는 일정기간 경과 후에 갈변반응에 관여 하는 기질이 감소하고, 다량의 갈변물질이 불용성의 고분자 화합물로 변화하므로 수용성 갈변물질은 상대적으로 감소되 어 갈색도가 오히려 낮아지는 것으로 보고되어 있다[21]. 본 연구결과 비극성인 chloroform과 hexane 분획물에서 갈변도 가 상대적으로 높은 것은 홍마늘 제조 과정 동안 장시간 고온 에서 처리됨으로 인해 수용성 갈변물질의 상대적인 양이 감소 하였기 때문인 것으로 생각된다.

\section{총 페놀 및 플라보노이드 함량}

홍마늘 용매별 분획물의 총 페놀 및 플라보노이드 함량을 측정한 결과는 Fig. 2와 같다. 총 페놀 함량은 hexnae 분획물 에서 $132.39 \mathrm{mg} / \mathrm{g}$ 으로 가장 높았으며, 다음으로 chloroform 분획물이었으며, butanol 분획물에서는 $35.13 \mathrm{mg} / \mathrm{g}$ 으로 가 장 낮은 함량이었다. 플라보노이드 함량도 hexane 분획물에 서 $16.22 \mathrm{mg} / \mathrm{g}$ 으로 가장 높았으며, 다음으로 chloroform 분 획물로 $10.69 \mathrm{mg} / \mathrm{g}$ 이었으며, 그 외 분획물에서는 $10 \mathrm{mg} / \mathrm{g}$ 이하였다.

Shin 등[26]은 흑마늘 용매별 분획물의 총 페놀 및 플라보노

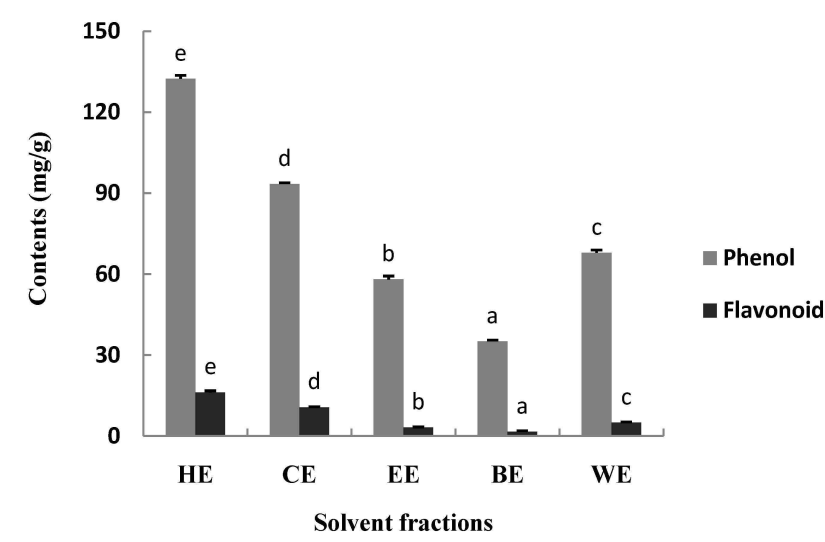

Fig. 2. Total phenol and flavonoid contents of solvent fractions from red garlic. HE: hexane extract, $\mathrm{BE}$ : butanol extract, CE: chloroform extract, EE: ethyl acetate extract, WE: water extract. Each value represents mean $\pm S D(n=3)$. ${ }^{\mathrm{a}-\mathrm{e}}$ Means with different superscripts in the bars are significantly different at $p<0.05$.
이드 함량은 chloroform 분획물에서 가장 높아 시료 중의 페놀 화합물이 비극성 물질이라고 추정한 바 있는데, 홍마늘 분획 물도 이와 유사한 경향이었다.

총 페놀 물질은 수산기로 인한 수소공여와 페놀 고리구조의 공명구조 안정화로 항산화 활성을 나타내는데, 흑양파에서는 갈변도가 높을수록 총 페놀 함량도 높은 경향을 나타낸다고 보고되어 있다[29].

플라보노이드와 탄닌을 중심으로 한 식물계의 폴리페놀 물 질은 식물체에 특수한 색을 부여하고 산화-환원반응에서 기질 로 작용하는데, 한 분자 내에 2개 이상의 phenolic hydroxyl 기를 가지는 방향족 화합물로서 항산화 활성 뿐만 아니라 충 치예방, 고혈압 억제, 항에이즈, 항산화, 항암 등의 생리활성을 가진다[14].

\section{DPPH 라디칼 소거능}

홍마늘 용매 분획물의 DPPH 라디칼 소거능을 62.5 1,000 $\mu \mathrm{g} / \mathrm{ml}$ 범위의 농도에서 측정한 결과는 Table 1 과 같다. 시료 의 농도 증가와 더불어 $\mathrm{DPPH}$ 라디칼 소거 활성도 증가하였는 데 $62.5 \mu \mathrm{g} / \mathrm{ml}$ 의 저농도에서는 물 분획물의 활성이 $13.37 \pm 0.96 \%$ 로 가장 높았다. $1,000 \mathrm{\mu g} / \mathrm{ml}$ 의 고농도에서는 chloroform 분획물에서 $48.64 \pm 0.32 \%$ 로 가장 활성이 높았고, ethyl acetate와 물 분획물이 $40 \%$ 이상으로 활성이 높았으나 butanol 추출물의 활성은 $12.74 \pm 0.52 \%$ 로 가장 낮았다.

흑마늘 용매별 분획물의 경우에도 chloroform 분획물에서 $\mathrm{DPPH}$ 라디칼 소거능이 가장 높아 $1,000 \mu \mathrm{g} / \mathrm{ml}$ 첨가시 $91.56 \%$ 였으며, 다음으로 ethyl acetate 분획물이 $87.08 \%$ 로 활 성이 높아 DPPH 라디칼 소거능이 높은 흑마늘 용매 분획물이 비극성 용매에 친화성이 강한 성분이라고 추정된 바 있는데 [26], 홍마늘도 이와 유사한 것으로 판단된다.

갈변반응에 의해서 생성된 갈변물질은 항산화능을 가지는 것으로 알려져 있는데, 백삼과 증삼 추출물을 $100^{\circ} \mathrm{C}$ 에서 갈색 화 시키면서 갈색도와 항산화능을 조사한 결과 갈색도가 높을 수록 $\mathrm{DPPH}$ 에 대한 수소공여능도 증가하였으나 갈변물질을 투석하여 분자량에 따라 나누고 갈색도와 항산화능을 조사하 였을 때는 갈색도가 더 낮은 투석 외핵의 항산화능이 더 높았

Table 1. DPPH radical scavenging activity of solvent fractions from red garlic

\begin{tabular}{lrrrrc}
\hline \multirow{2}{*}{ Solvent fractions } & \multicolumn{5}{c}{ Concentration $(\mu \mathrm{g} / \mathrm{ml})$} \\
\cline { 2 - 6 } & \multicolumn{1}{c}{125} & \multicolumn{1}{c}{250} & \multicolumn{1}{c}{500} & 1000 \\
\hline Hexane & $6.59 \pm 0.51^{\mathrm{aA}}$ & $7.19 \pm 1.17^{\mathrm{aA}}$ & $11.49 \pm 0.76^{\mathrm{bB}}$ & $0.17 \pm 0.60^{\mathrm{CB}}$ & $28.87 \pm 0.45^{\mathrm{dB}}$ \\
Chloroform & $11.44 \pm 0.88^{\mathrm{aB}}$ & $11.65 \pm 0.22^{\mathrm{aB}}$ & $18.19 \pm 0.42^{\mathrm{bC}}$ & $29.91 \pm 0.22^{\mathrm{CE}}$ & $48.64 \pm 0.32^{\mathrm{dE}}$ \\
Ethyl acetate & $11.90 \pm 0.17^{\mathrm{aB}}$ & $12.21 \pm 1.40^{\mathrm{aB}}$ & $16.72 \pm 2.55^{\mathrm{bC}}$ & $28.09 \pm 1.49^{\mathrm{CD}}$ & $43.34 \pm 1.52^{\mathrm{dD}}$ \\
Butanol & $7.01 \pm 0.74^{\mathrm{aA}}$ & $6.96 \pm 0.56^{\mathrm{aA}}$ & $8.17 \pm 0.96^{\mathrm{bA}}$ & $9.87 \pm 0.37^{\mathrm{CA}}$ & $12.74 \pm 0.52^{\mathrm{dA}}$ \\
Water & $13.37 \pm 0.96^{\mathrm{aC}}$ & $16.25 \pm 0.36^{\mathrm{bC}}$ & $17.40 \pm 0.69^{\mathrm{CC}}$ & $26.83 \pm 0.66^{\mathrm{dC}}$ & $41.14 \pm 0.55^{\mathrm{eC}}$ \\
\hline
\end{tabular}

Each value represents mean \pm SD $(n=3)$.

${ }^{\mathrm{a}-\mathrm{e}}$ Means with different superscripts in the same row are significantly different at $p<0.05$.

${ }^{\mathrm{A}-\mathrm{E}}$ Means with different superscript in the same column are significantly different at $p<0.05$. 
다는 보고[16]로 볼 때 갈변도와 항산화 활성은 반드시 일치하 는 경향을 나타내는 것은 아니며, 분획물에 함유된 물질에 따 라 활성에 차이가 있음을 알 수 있다.

\section{ABTS 라디칼 소거능}

홍마늘 용매별 분획물의 ABTS 라디칼 소거능은 Table 2와 같다. 시료의 첨가 농도가 증가함에 따라 ABTS 라디칼 소거능 은 유의적으로 상승하였으며, $1,000 \mu \mathrm{g} / \mathrm{ml}$ 첨가시 chloroform, ethyl acetate 및 물 분획물에서 $70 \%$ 이상의 소거능을 보였으나, hexane 및 butanol 분획물의 경우에는 $50 \%$ 미만으 로 활성이 낮았다. 특히 chloroform 분획물의 경우, 본 실험에 서 사용한 농도인 $62.5 \sim 500 \mu \mathrm{gg} / \mathrm{ml}$ 의 농도범위에서 타 분획물 에 비해 유의적으로 높은 소거능을 보였으며, 다음으로는 물 분획물의 순이었다.

라디칼 소거능의 비교에서 ABTS법은 양이온을 소거한다는 점에서 유리 라디칼을 소거하는 $\mathrm{DPPH}$ 법에 비해 다소간 활성 이 높은 것으로 알려져 있다[27]. 이러한 결과는 본 실험과도 유사하였으며, 홍마늘 chloroform 분획물이 타 분획물보다 ABTS 소거능이 높았던 것은 흑마늘의 용매별 분획물[26]과도 잘 일치하는 결과였다. 홍마늘 열수추출물의 ABTS 라디칼 소 거능은 생마늘에 비해서는 높고 흑마늘에 비해서는 낮은 것으 로 보고[19]되어 있는데 열처리에 의한 숙성 기간과 정도에 따라 갈변물질의 생성이 다르기 때문에 라디칼 소거능에도 차이를 보이는 것으로 생각된다.

\section{FRAP법에 의한 항산화능}

FRAP법에 의한 항산화능의 측정은 산성 $\mathrm{pH}$ 영역에서 ferric tripyridyltriazine $\left(\mathrm{Fe}^{3+}-\mathrm{TPTZ}\right)$ 복합체가 환원성 물질에 의 해 청색의 ferrous tripyridyltriazine $\left(\mathrm{Fe}^{2+}-\mathrm{TPTZ}\right)$ 으로 환원되 는 원리를 이용한 것으로 대부분의 항산화제가 환원력을 가지 고 있다는 점에 착안하여 고안된 방법이다[2].

홍마늘 용매별 분획물의 항산화능을 측정하여 $\mathrm{FeSO}_{4}$ 당량 으로 나타낸 결과는 Table 3 과 같이 시료의 첨가 농도에 의존 적으로 항산화능이 증가하였다. 특히 chloroform 분획물이 가 장 높은 항산화능을 보였고, 다음으로는 hexane 분획물 이었 다. Butanol 분획물의 경우에는 $62.5 ~ 250 \mu \mathrm{g} / \mathrm{ml}$ 의 농도 범위 에서 항산화능이 나타나지 않았으며, $1,000 \mathrm{\mu g} / \mathrm{ml}$ 의 농도에서 도 $37.22 \mu \mathrm{M}$ 로 가장 활성이 낮았다. Chloroform 분획물은 butanol 분획물에 비해서는 약 25.1배 정도 높은 활성을 보였다. 홍마늘 분획물의 항산화능은 전반적으로 chloroform, hexane 분획물에서 높게 나타났는데, chloroform 분획물은 hexane 분 획물에 비해 갈변물질의 함량이 약 1.7 배 정도 높았으며, hexane 분획물은 chloroform 분획물에 비해 총 페놀 및 플라보노 이드 함량이 유의적으로 높았다.

숙성마늘 중의 대표적인 수용성 화합물인 S-allylcysteine (SAC)과 S-allylmercaptocysteine (SAMC), 지용성 화합물인 diallyl sulfide (DAS), triallyl sulfide, diallyl disulfide (DADS), diallyl polysulfide 및 allixin과 같은 phenolic 화합 물, n-fructosyl glutamate, n-fructosyl arginine, 셀레늄 등은

Table 2. ABTS radical scavenging activity of solvent fractions from red garlic

\begin{tabular}{lrrrrc}
\hline \multirow{2}{*}{ Solvent fractions } & \multicolumn{5}{c}{ Concentration $(\mu \mathrm{g} / \mathrm{ml})$} \\
\cline { 2 - 6 } & \multicolumn{1}{c}{62.5} & 125 & 250 & 500 & 1000 \\
\hline Hexane & $8.31 \pm 0.69^{\mathrm{aB}}$ & $12.94 \pm 0.57^{\mathrm{bB}}$ & $81.58 \pm 0.45^{\mathrm{cB}}$ & $32.14 \pm 1.29^{\mathrm{dB}}$ & $47.30 \pm 1.02^{\mathrm{eB}}$ \\
Chloroform & $25.15 \pm 0.63^{\mathrm{aD}}$ & $36.77 \pm 1.63^{\mathrm{bE}}$ & $51.27 \pm 1.37^{\mathrm{CE}}$ & $70.01 \pm 0.75^{\mathrm{dE}}$ & $72.62 \pm 0.49^{\mathrm{eC}}$ \\
Ethyl acetate & $8.39 \pm 0.73^{\mathrm{aB}}$ & $17.45 \pm 1.06^{\mathrm{bC}}$ & $31.70 \pm 0.67^{\mathrm{CC}}$ & $56.13 \pm 1.50^{\mathrm{dC}}$ & $76.62 \pm 0.60^{\mathrm{eD}}$ \\
Buthanol & $3.82 \pm 0.57^{\mathrm{aA}}$ & $2.68 \pm 1.01^{\mathrm{aA}}$ & $6.57 \pm 1.05^{\mathrm{bA}}$ & $16.35 \pm 0.99^{\mathrm{cA}}$ & $32.80 \pm 0.37^{\mathrm{dA}}$ \\
Water & $10.66 \pm 0.32^{\mathrm{aC}}$ & $33.78 \pm 1.42^{\mathrm{bD}}$ & $33.61 \pm 0.79^{\mathrm{bD}}$ & $57.94 \pm 0.55^{\mathrm{cD}}$ & $77.68 \pm 0.66^{\mathrm{dE}}$ \\
\hline
\end{tabular}

Each value represents mean $\pm S D(n=3)$.

${ }^{\mathrm{a}-\mathrm{e}}$ Means with different superscripts in the same row are significantly different at $p<0.05$.

${ }^{\mathrm{A}-\mathrm{E}}$ Means with different superscript in the same column are significantly different at $p<0.05$.

Table 3. Ferric reducing antioxidant power of solvent fractions from red garlic

$\left(\mathrm{FeSO}_{4}\right.$ eq $\left.\mu \mathrm{M}\right)$

\begin{tabular}{lccccc}
\hline \multirow{2}{*}{ Solvent fractions } & \multicolumn{5}{c}{ Concentration $(\mu \mathrm{g} / \mathrm{ml})$} \\
\cline { 2 - 6 } & 62.5 & 125 & 250 & 500 & 1000 \\
\hline Hexane & $13.33 \pm 1.67^{\mathrm{aB}}$ & $38.40 \pm 2.95^{\mathrm{bC}}$ & $125.55 \pm 2.55^{\mathrm{CC}}$ & $342.96 \pm 2.24^{\mathrm{dD}}$ & $892.07 \pm 3.59^{\mathrm{eD}}$ \\
Chloroform & $33.33 \pm 1.67^{\mathrm{aE}}$ & $92.34 \pm 0.88^{\mathrm{bD}}$ & $244.44 \pm 3.47^{\mathrm{CE}}$ & $488.56 \pm 3.36^{\mathrm{dE}}$ & $934.44 \pm 5.36^{\mathrm{eE}}$ \\
Ethyl acetate & $17.18 \pm 1.89^{\mathrm{aD}}$ & $96.11 \pm 0.96^{\mathrm{bE}}$ & $175.56 \pm 1.93^{\mathrm{CD}}$ & $338.33 \pm 6.67^{\mathrm{dC}}$ & $562.22 \pm 4.81^{\mathrm{eC}}$ \\
Butanol & $-^{\mathrm{A}}$ & $-\mathrm{A}$ & $-{ }^{\mathrm{A}}$ & $15.11 \pm 2.79^{\mathrm{dA}}$ & $37.22 \pm 0.96^{\mathrm{eA}}$ \\
Water & $16.11 \pm 0.96^{\mathrm{aC}}$ & $25.55 \pm 2.55^{\mathrm{bB}}$ & $116.11 \pm 4.19^{\mathrm{cB}}$ & $272.22 \pm 1.92^{\mathrm{dB}}$ & $522.78 \pm 4.81^{\mathrm{eB}}$ \\
\hline
\end{tabular}

Each value represents mean \pm SD $(n=3)$.

${ }^{a-e}$ Means with different superscripts in the same row are significantly different at $p<0.05$.

${ }^{\mathrm{A}-\mathrm{E}}$ Means with different superscript in the same column are significantly different at $p<0.05$. 
Table 4. Lipase inhibition activity of solvent fractions from red garlic

$(\%)$

\begin{tabular}{lccccc}
\hline \multirow{2}{*}{ Solvent fractions } & \multicolumn{5}{c}{ Concentration $(\mu \mathrm{g} / \mathrm{ml})$} \\
\cline { 2 - 6 } & \multicolumn{6}{c}{62.5} & 125 & 250 & 500 & 1000 \\
\hline Hexane & $19.38 \pm 0.20^{\mathrm{aD}}$ & $22.85 \pm 0.52^{\mathrm{bB}}$ & $25.92 \pm 0.09^{\mathrm{cC}}$ & $27.04 \pm 0.37^{\mathrm{dB}}$ & $35.68 \pm 0.18^{\mathrm{eC}}$ \\
Chloroform & $21.46 \pm 0.17^{\mathrm{aE}}$ & $31.69 \pm 1.04^{\mathrm{bD}}$ & $39.45 \pm 0.30^{\mathrm{CE}}$ & $43.01 \pm 0.53^{\mathrm{dD}}$ & $46.68 \pm 0.07^{\mathrm{eE}}$ \\
Ethyl acetate & $15.23 \pm 0.23^{\mathrm{aB}}$ & $26.53 \pm 0.24^{\mathrm{bC}}$ & $29.43 \pm 0.86^{\mathrm{CD}}$ & $33.51 \pm 0.07^{\mathrm{dC}}$ & $37.28 \pm 0.04^{\mathrm{eD}}$ \\
Butanol & $6.89 \pm 0.13^{\mathrm{aA}}$ & $18.70 \pm 0.06^{\mathrm{bA}}$ & $23.59 \pm 0.03^{\mathrm{cA}}$ & $25.30 \pm 0.28^{\mathrm{dA}}$ & $26.86 \pm 0.50^{\mathrm{eB}}$ \\
Water & $16.17 \pm 0.17^{\mathrm{aC}}$ & $19.05 \pm 0.10^{\mathrm{bA}}$ & $24.47 \pm 0.42^{\mathrm{cB}}$ & $26.99 \pm 0.69^{\mathrm{dB}}$ & $20.69 \pm 0.36^{\mathrm{eA}}$ \\
\hline
\end{tabular}

Each value represents mean \pm SD $(n=3)$.

${ }^{\mathrm{a} e \mathrm{e}}$ Means with different superscripts in the same row are significantly different at $p<0.05$.

${ }^{\mathrm{A}-\mathrm{E}}$ Means with different superscript in the same column are significantly different at $p<0.05$.

항산화 활성을 나타내는 대표적인 물질들이며, 이들이 숙성마 늘의 항산화 활성에 크게 기여한다고 알려져 있다[3].

\section{Lipase 활성저해능}

홍마늘 용매별 분획물의 lipase 저해활성을 측정한 결과는 Table 4 와 같다. $62.5 \mu \mathrm{g} / \mathrm{ml}$ 의 저농도에서는 chloroform 분획 물에서 가장 활성이 높아 $21.46 \pm 0.17 \%$ 였고, buthanol 분획물 에서 가장 활성이 낮아 $6.89 \pm 0.13 \%$ 에 불과하였다. 시료의 농도 가 증가하면서 lipase 저해활성도 증가하였는데, $500 \mu \mathrm{g} / \mathrm{ml}$ 농도에서는 $25 \%$ 이상으로 활성이 증가하였다. 그러나 $500 \mu$ $\mathrm{g} / \mathrm{ml}$ 에서 $1,000 \mathrm{\mu g} / \mathrm{ml}$ 로 시료의 첨가 농도가 2 배 증가하였으 나 물 분획물에서는 오히려 활성이 감소하였고, 그 외 시료의 활성은 $1.03 ~ 1.32$ 배 증가하여 상대적인 활성의 증가폭이 적었 다. Butanol 분획물의 경우도 $250 \mathrm{\mu g} / \mathrm{ml}$ 이상의 농도에서 lipase 저해활성은 $23.59 \pm 0.03 \sim 26.86 \pm 0.50 \%$ 로 활성의 증가가 적 어 홍마늘 추출물은 일정농도 이상에서 활성에 큰 차이를 나 타내지 않았다.

상황버섯 용매 계통 추출물의 lipase 저해활성은 hexane과 ethyl acetate 추출물에서는 $70 \%$ 이상으로 활성이 높았으나 chloroform과 물추출물의 활성은 $21 \%$ 미만으로 추출용매 특 이성에 따른 활성의 차이는 없는 것으로 보고되어 있는데[15], 이는 본 연구의 결과와도 유사한 경향이었다.

지방의 분해 및 흡수와 관련된 효소 중 pancreatic lipase는 triacylglycerol을 2-monoacylglycerol과 두 분자의 fatty acid 로 분해하는 핵심적인 반응을 진행시키는 효소로 작용한다 [20]. 따라서 지방의 분해에 관여하는 효소의 활성을 저해하여 소화를 방해함으로써 체내로의 지방 흡수를 억제하게 되어 비만억제 활성을 나타낼 것으로 기대된다. Ballinger와 Peikin [1]에 의하면 시판되는 장관 내 lipase 저해제인 orlistat (상품 명; xenical (R))는 위장과 소장의 관강 내에서 위와 췌장의 지방분해효소의 활성부위인 serine과의 공유결합을 형성하여 lipase를 불활성화시킴으로써 항비만 약제 기능을 하는데, 주 로 지방변과 같은 소화기계 증상의 부작용을 나타내는 것으로 알려져 있다.

최근, 지방소화 억제를 통해 항비만 활성의 천연물 소재를

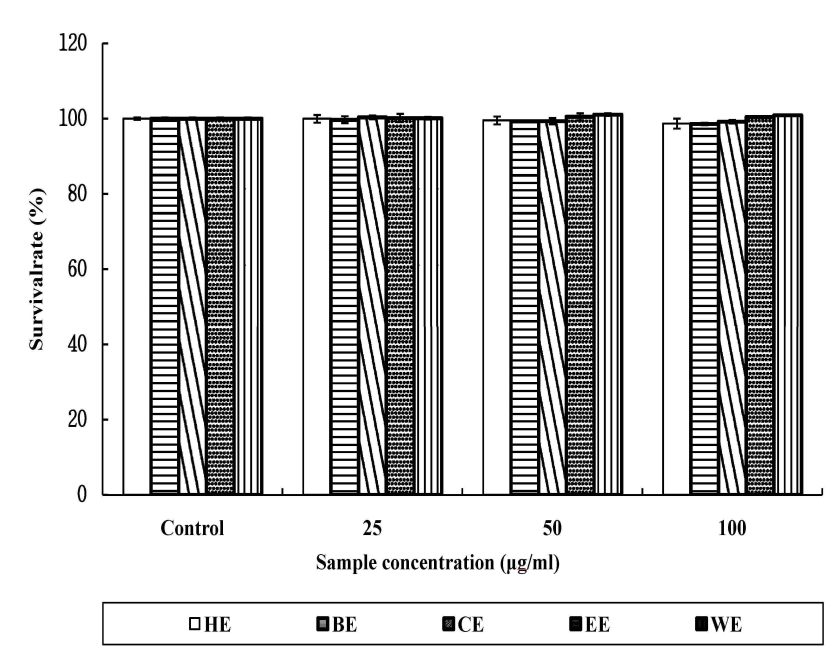

Fig. 3. Effect of red garlic solvent extract on 3T3-L1 preadipocytes proliferation. HE: hexane extract, BE: butanol extract, CE: chloroform extract, EE: ethylacetate extract, WE: water extract. Each value represents mean $\pm S D(n=3)$.

탐색하기 위한 연구들이 진행되고 있는데, 부작용이 없어 상 시 섭취가 가능하다는 점에서 이와 관련한 연구는 지속적으로 추진되어야 할 것이다.

\section{항비만 활성}

홍마늘 용매 분획물의 항비만 활성 평가에 이용된 3T3-L1 세포에 대한 세포독성을 평가한 결과(Fig. 3) 최고 농도에서도 세포 생존율은 $98.61 \%$ 이상으로 실험에 사용된 $100 \mathrm{\mu g} / \mathrm{ml}$ 까 지는 세포 생장에 영향을 미치지 않음을 확인할 수 있었다.

세포독성 평가 결과에 따라 최고 농도인 $100 \mu \mathrm{\mu g} / \mathrm{ml}$ 에서 항비만 활성을 평가하였다. 3T3-L1 지방 세포의 분화과정에 홍마늘 계통 분획물을 처리한 후 세포내 지방축적량을 측정함 으로서 항비만 활성을 평가한 결과는 Fig. 4 와 같다. 대조군에 비해 홍마늘 분획물을 처리함으로서 유의적으로 지방 축적율 이 감소하였다. 가장 활성이 높은 물분획물의 대조군에 대비 지방축적율은 $50.24 \%$ 였으며, 다음으로 butanol과 ethyl acetate 분획물이 각각 $62.80 \%$ 와 $64.73 \%$ 로 대조군 대비 지방 


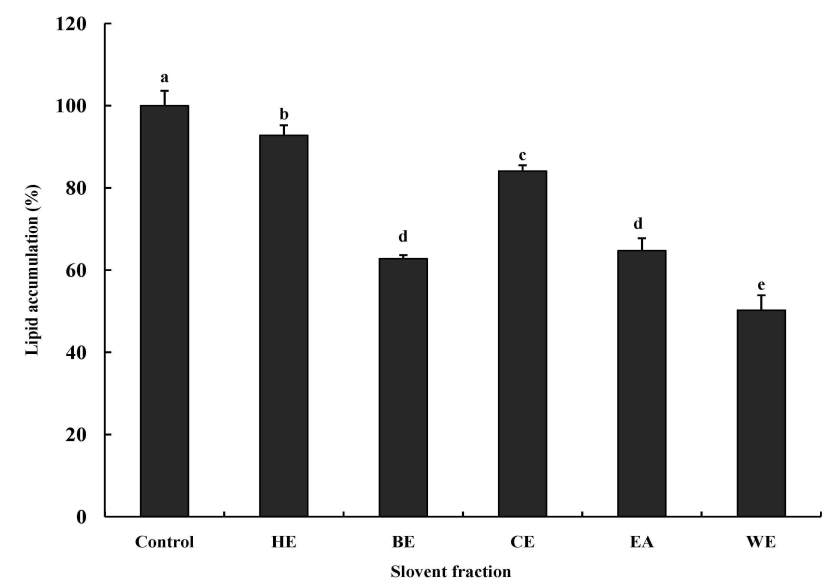

Fig. 4. Effect of red garlic solvent extract on the lipid content in 3T3-L1 adipocytes. HE: hexane extract, BE: butanol extract, CE: chloroform extract, EE: ethyl acetate extract, WE: water extract. Each value represents mean \pm SD $(n=3) .{ }^{\text {a-e }}$ Means with different superscripts in the bars are significantly different at $p<0.05$.

축적율이 낮았으며, 용매 분획물 중 가장 활성이 낮았던 hexane 분획물의 지방 축적 억제율은 약 $8 \%$ 정도에 불과하였다.

Park 등[20]은 생마늘 열수추출물에 비해 흑마늘 열수추출 물을 처리함으로서 중성지질의 축적율이 유의적으로 감소하 였는데, 흑마늘 열수추출물은 지방전구세포의 분화를 억제함 으로서 비만 예방에 효과가 기대된다고 보고한 바 있다. 비만 은 과도한 에너지 섭취에 의한 체내 지방조직의 축적에 의한 것으로 지방조직을 구성하는 지방세포의 크기나 수가 비정상 적으로 증가하는 상태인데, 전지방세포로부터 지방세포로 분 화를 억제하는 활성을 가진 식품은 비만을 예방하는 활성을 가질 것으로 기대되고 있다[10].

\section{감사의 글}

본 연구는 농림부에서 시행한 농림기술개발사업(10913703-1-HD110)의 연구과제로 수행된 결과의 일부이며 이에 감 사드립니다.

\section{References}

1. Ballinger, A. and Peikin, S. R. 2002. Orlistat: its current status as an anti-obesity drug. Eur. J. Pharmacol. 440, 109-117.

2. Benzie, I. F. and Strain, J. J. 1996. The ferric reducing ability of plasma (FRAP) as a measure of "antioxidant power": the FRAP assay. Anal. Biochem J. 239, 70-76.

3. Bitou N., Nimomiya, M. Tsjita, T. and Okuda, H. 1999. Screening of lipase inhibitors from marine algae. Lipids 34, 441-445.

4. Borek, C. 2001. Antioxidant health effects of aged garlic extract. J. Nutr. 1010s-1015s.
5. Choi, D. J., Lee, S. J. Kang, M. J. Cho, H. S. Sung, N. J. and Shin, J. H. 2008. Physicochemical characteristics of black garlic (Allium sativum L.). J. Korean Soc. Food Sci. Nutr. 37, 465-471.

6. Hwang, T. Y., Sohn, K. H., Lim, J. H. and Moon, K. D. 2010. Antibrowning effect of Licorice(Glycyrrhiza glabra) extracts on chopped garlic. Korean J. Food Preserv. 17, 160-164.

7. Jeong, Y. Y., Park, H. J., Cho, Y. W., Kim, E. J., Kim, G. T., Mun, Y. J., Lee, J. D., Shin, J. H., Kang, D. W. and Han, J. H. 2012. Aged red garlic extract reduces cigarette smoke extract-induced cell death in human bronchial smooth muscle cells by increasing intracellular glutathione levels. Phytother. Res. 26, 18-25.

8. Kang, M. J., Lee, S. J., Shin, J. H., Kang, S. K., Kim, J. G. and Sung, N. J. 2008. Effect of garlic with different processing on lipid metabolism in 1\% cholesterol fed rats. J. Korean Soc. Food Sci. Nutr. 37, 162-1699.

9. Kang, M. J., Yoon, H. S., Jeong, S. H., Sung, N. J. and Shin, J. H. 2011. Physicochemical characteristics of red garlic during processing. Korean J. Food Preserv. 18, 896-906.

10. Kim, D. J., Jung, J. H., Kim, S. G., Lee, H. K., Lee, S. K., Hong, H. D., Lee, B. Y. and Lee, O. H. 2011. Antioxidants and anti-obesity activities of hot water and ethanolic extracts from Cheonnyuncho (Opuntia humifusa). Korean J. Food Preserv. 18, 366-373.

11. Kim, S. B., Lee, D. H., Yeum, D. Y., Park, J. W., Do, J. R. and Park, Y. H. 1998. Nitrite scavenging effect of Maillard reaction products derived from glucose-amino acids. Korean J. Food Sci. Technol. 20, 453-458.

12. Kim, S. B., Park, Y. H., Hayase, F. and Kato, H. 1986. Desmutagenic effects of Maillard reaction products against mutagenic heterocyclic amines. Bull. Korean Fish Soc. 19, 127-135.

13. Kim, S. H. and Baek, Y. H. 2011. Effects of aerobic exercise and black garlic intake on blood lipids, lipid peroxidation and BAP in rats. J. Life Sci. 21, 1025-1031.

14. Lee, B. B., Park, S. R., Han, C. S., Han, D. Y., Park, E. J., Park, H. R. and Lee, S. C. 2008. Antioxidant activity and inhibition activity against a-amylase and a-gluosidase of Viola mandshurica extracts. Korean Soc. Food Sci. Nutr. 37, 405-409.

15. Lee J. K., Song, J. H. and Lee, J. S. 2010. Purification of anti-obesity lipase inhibitor from the fruiting body of Phellinus linteus. Kor. J. Mycol. 38, 57-61.

16. Lee, J. W. and Do, J. H. 2006. Current studies on browning reaction products and acidic polysaccharide in Korean red ginseng. J. Ginseng Res. 30, 41-48.

17. Lee, J. W., Park, C. K. and Do, J. H. 2005. Antioxidative activity of the water soluble browning reaction products from Korean red ginseng. J. Ginseng Res. 29, 44-48.

18. Lee, S. H., Hwang, I. G., Lee, Y. R., Joung, E. M., Jeong, H. S. and Lee, H. B. 2009. Physicochemical characteristics and antioxidant activity of heated radish(Raphanus sativus L.) extracts. J. Korean Soc. Food Sci. Nutr. 38, 490-495.

19. Lee, S. J., Shin, J. H., Kang, M. J., Jung, W. J., Ryu, J. H., Kim, R. J. and Sung, N. J. 2010. Antioxidants activity of aged 
red garlic. J. Life Sci. 20, 775-781.

20. Park, J. A., Park, C., Han, M. H., Kim, B. W., Chung, Y. H. and Cho, Y. H. 2011. Inhibition of adipocyte differentiation and adipogenesis by aged black garlic extracts in 3T3-L1 preadipocytes. J. Life Sci. 21, 720-728.

21. Park, N. Y., Jeong, Y. J., Lee, G. D. and Kwon, J. H. 2000. Monitoring of Maillard reaction characteristics under various roasting conditions of Polygonatum odoratum root. J. Korean Soc. Food Sci. Nutr. 29, 647-654.

22. Saisuburamaniyan, N., Krithika, L., Dileena, K. P., Sivasubramanian, S. and Puvanakrishnan, R. 2004. Lipase assay in soils by copper soap colorimetry. Anal. Biochem 33, 70-73.

23. Shin, J. H., Choi, D. J., Lee, S. J., Cha, J. Y., Kim, J. G. and Sung, N. J. 2008. Changes of physicochemical components and antioxidant activity of garlic during its processing. J. Life Sci. 18, 1123-1131.

24. Shin, J. H., Choi, D. J., Lee, S. J., Cha, J. Y. and Sung, N. J. 2008. Antioxidant activity of black garlic (Allium sativum L.). J. Korean Soc. Food Sci. Nutr. 37, 965-971.

25. Shin, J. H., Kang, M. J., Kim, R. J., Ryu, J. H., Kim, M. J., Lee, S. J. and Sung, N. J. 2011. Biological activity of browning compounds from processed garlics separated by dialysis membrane. J. Korean Soc. Food Sci. Nutr. 40, 357-365.
26. Shin, J. H., Lee, H. G., Kang, M. J., Lee, S. J. and Sung, N. J. 2010. Antioxidant activity of solvent fraction from black garlic. J. Korean Soc. Food Sci. Nutr. 39, 933-940.

27. Wang, M. F., Shao, Y., Yi, J. G., Zhu, N. O., Rngarajan, M., Lavoic, E. J. and Ho, C. T. 1998. Antioxidative phenolic compounds from sage(Salivia officinalis). J. Agric. Food Chem 46, 4869-4873.

28. Yamabe, N., Lee, J. G., Lee, Y. J., Park, C. H., Kim, H. Y., Park, J. H., Yokozawa, T. and Kang, K. S. 2011. The chemical and 1,1-diphenyl-2-picrylhydrazyl radical scavenging activity changes of ginsenosides $\mathrm{Rb} 1$ and $\mathrm{Rg} 1$ by Maillard reaction. J. Ginseng Res. 35, 60-68.

29. Yang, Y. R. and Park, Y. K. 2011. Black onions manufactured via the browning reaction and antioxidant effects of their water extracts. Korean J. Food Preserv. 18, 310-318.

30. You, B. J. 1993. Isolation of antioxidative substances from browning reaction product obtained from L-ascorbic acid solution. Korean J. Food Sci. Technol. 25, 214-219.

31. You, B. R., Kim, H. R., Kim, M. J. and Kim, M. R. 2011. Comparison of the quality characteristics and antioxidant activities of the commercial black garlic and lab-prepared fermented and aged black garlic. J. Korean Soc. Food Sci. Nutr. 40, 366-371.

\title{
초록 : 홍마늘 용매 분획물의 항산화 및 항비만 활성
}

\author{
황초롱 $^{1} \cdot$ 신정혜 $^{1} \cdot$ 강민정 $^{1} \cdot$ 이수정 $^{2} \cdot$ 성낙주 $^{2}{ }^{\star}$ \\ ${ }^{1}\left({ }^{(}\right.$ㅐㅐ)남해마늘연구소, ${ }^{2}$ 경상대학교 식품영양학과 · 농업생명과학연구원)
}

열처리를 통한 새로운 마늘 가공품의 개발 및 그 생리활성 규명을 위한 연구의 일환으로 새로이 개발된 홍마늘 의 용매별 계통 분획물을 제조하고, 항산화 활성과 항비만 활성을 중심으로 한 생리활성을 비교 분석하였다. 홍마 늘 계통 분획물 중 갈변물질의 함량은 chloroform 분획물에서 가장 높았고, 총 페놀 화합물과 플라보노이드 함량 은 hexane 분획물에서 가장 높은 함량이었고, 다음으로 chloroform 분획물의 순이었다. DPPH와 ABTS 라디칼 소거능 및 FRAP법에 의한 항산화능도 chloroform 분획물이 타 분획물에 비해 유의적으로 높은 활성을 나타내었 다. 항산화 활성은 갈변물질의 함량이 높고, 총 페놀 화합물 및 플라보노이드의 함량이 높은 hexane 및 chloroform 화합물에서 활성이 높아 홍마늘 분획물의 항산화능은 이들 물질의 상호작용에 의한 결과로 추정된다. Pancreatic lipase 저해활성은 $500 \mu \mathrm{g} / \mathrm{ml}$ 미만의 농도에서는 농도 증가와 더불어 유의적으로 활성이 증가하였으 며, 가장 활성이 높았던 chloroform 분획물에서 $40 \%$ 이상의 활성을 나타내었다. 항산화 활성 분석의 결과에서 활성이 높았던 hexane 및 chloroform 분획물의 지방세포 분화와 지방 축적 억제 활성은 여타 분획물에 비해 상대 적으로 낮았다. 항산화 활성과 항비만 활성이 일치하는 경향을 나타내지 않았는데, 이는 홍마늘 중의 항산화 활성 물질은 주로 비극성이며, 지방 축적 억제 활성이 있는 물질은 주로 극성에 대한 용해성이 더 높기 때문으로 추정 되며, 이와 관련하여서는 향후 더 많은 연구가 진행되어야 할 것으로 생각된다. 